\title{
2 甘味料とその甘味の測定
}

\section{渡 辺 長 男*}

\section{$2 \cdot 1$ はじめに}

味覚を数量的に扱うことは，食品製造にとってきわわ て望ましいことではあるが，まだじゅうぶんに研究され た分野ではない，広く人々に愛好される味覚の一つに甘 味があるが，甘味を有する物質は多岐にわたり，その物 理的性質や化学構造と味覚との関係は, 今の時点では甘 味物質全体を統一できるような法則は見いだされていな い. 個々の甘味物質についての定量方析方法もいるいる 研究されているが，甘味の計測化にはふじゅうぶんであ って, 官能検査による甘味度が甘味を計測化した唯一の ものである.しかしその測定方法も評価も，かなりばく 然としたものである. 以下本稿では食品製造の立場か ら，甘味の測定と評価について二，三の知見を述べてみ たい.

\section{$2 \cdot 2$ 甘味料とは}

甘味のあるものをカロリ一源としてみる一般の傾向に は，うまいものは栄養があるという本能的な考元方が根 底をなしていると思うが，本質的にみれば，代表的な甘 味料の砂糖そのものは必すの栄養素ではない，特に最近 は肥満による美容容姿の悪変に悩む人々や，肥満に基ゔ く糖尿病，心臟病，高血圧症患者などには，低糖分・低 カロリーの甘味食品が強く要望されている.

今までに合成方法や化学構造の明らかにされた化学物 質は，表 1 にも例示したように数多くあるが，化学構造 と甘味との相関性について体系的な定説はなく，偶然に 甘味を有することが発見されたものが多い，また，甘味 が強いからといってただちに食品に使用することはでき ない，食品に使用する甘味料としては，i）毒性・有害

表 1 交献に見られる甘味物質の化学構造と甘味度

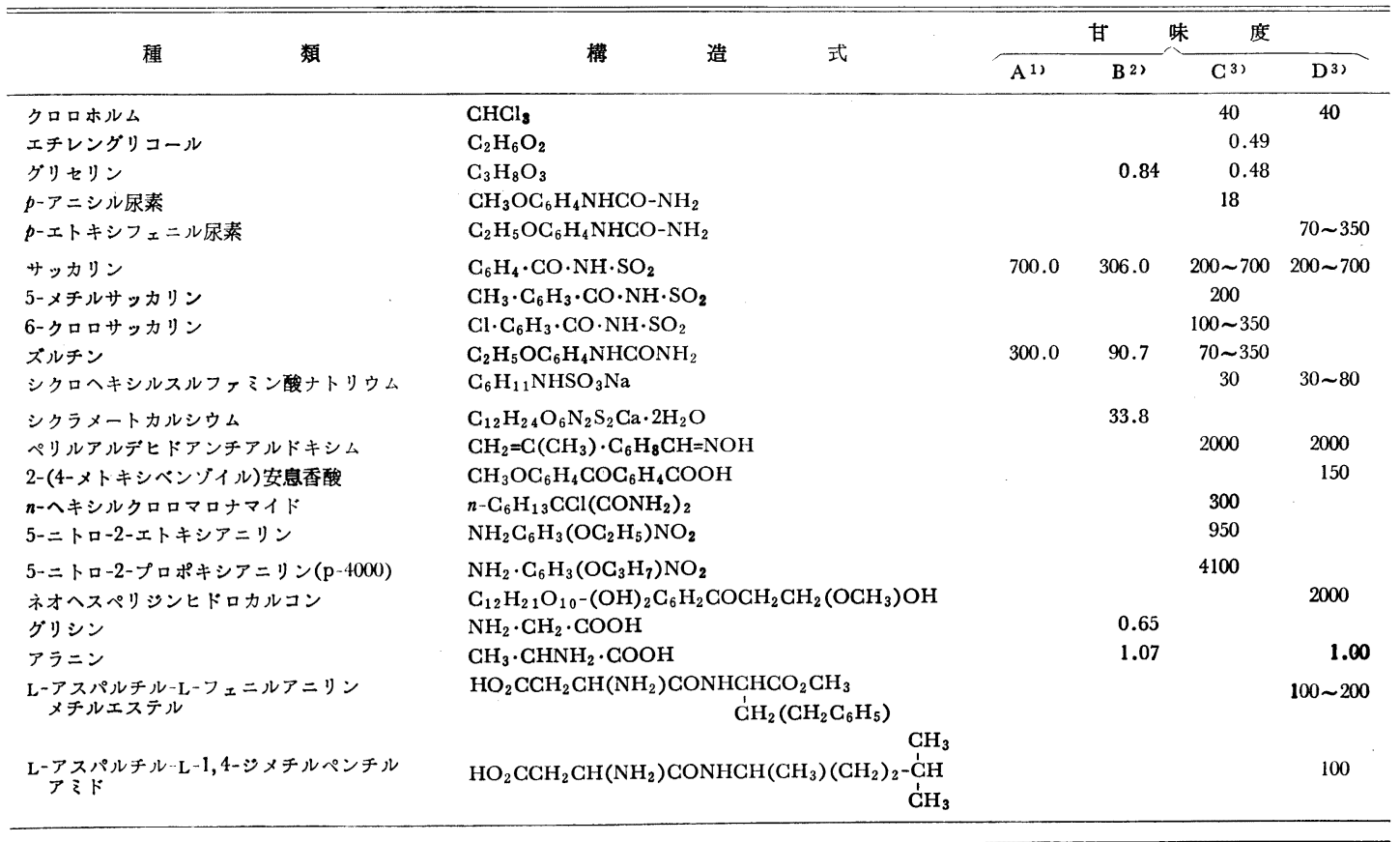

* 社団法人食生活開発研究所 : 東京都台東区入谷 1-18-7 
表 2 糖および糖アルコールの甘味度表

\begin{tabular}{|c|c|c|c|c|c|c|c|c|c|}
\hline \multicolumn{3}{|c|}{ 種 } & \multicolumn{2}{|l|}{ 類 } & \multicolumn{2}{|r|}{ 甘 } & \multirow{2}{*}{$\underbrace{\text { 味 }}_{C^{3)}}$} & \multicolumn{2}{|l|}{ 度 } \\
\hline 分 & 類 & 名 称 & 化 & 学 & $\mathrm{A}^{11}$ & B 2) & & $\left.\mathrm{D}^{3}\right)$ & $\mathrm{E}^{4)}$ \\
\hline 単糖類 & $\left\{\begin{array}{c}\text { 五炭糖 } \\
\text { 宸桾 } \\
" \prime \\
" 1\end{array}\right.$ & 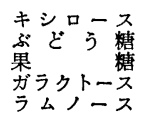 & \multicolumn{2}{|c|}{$\begin{array}{l}\mathrm{C}_{5} \mathrm{H}_{10} \mathrm{O}_{5} \\
\mathrm{C}_{6} \mathrm{H}_{12} \mathrm{O}_{6} \\
\mathrm{C}_{6} \mathrm{H}_{12} \mathrm{O}_{6} \\
\mathrm{C}_{6} \mathrm{H}_{12} \mathrm{O}_{6} \\
\mathrm{C}_{6} \mathrm{H}_{12} \mathrm{O}_{6}\end{array}$} & $\begin{array}{l}0.40 \\
0.74 \\
1.75 \\
0.32 \\
0.32\end{array}$ & $\begin{array}{c}0.61 \sim 0.64 \\
1.15 \\
0.59\end{array}$ & $\begin{array}{l}0.5 \sim 0.6 \\
1.0 \sim 1.5\end{array}$ & $\begin{array}{c}0.4 \\
0.64 \sim 0.74 \\
1.15 \sim 1.73 \\
0.32 \sim 0.67 \\
0.32\end{array}$ & $\begin{array}{r}67 \\
69 \\
114 \\
63 \\
33\end{array}$ \\
\hline 少桾類 & $\left\{\begin{array}{l}\text { 二糖類 } \\
" \prime \\
\text { 三糖類 }\end{array}\right.$ & 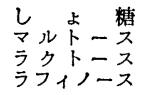 & \multicolumn{2}{|c|}{$\begin{array}{l}\mathrm{C}_{12} \mathrm{H}_{22} \mathrm{O}_{11} \\
\mathrm{C}_{12} \mathrm{H}_{22} \mathrm{O}_{11} \\
\mathrm{G}_{12} \mathrm{H}_{22} \mathrm{O}_{11} \\
\mathrm{C}_{18} \mathrm{H}_{32} \mathrm{O}_{16}\end{array}$} & $\begin{array}{l}1.00 \\
0.32 \\
0.16 \\
0.23\end{array}$ & $\begin{array}{l}1.00 \\
0.46 \\
0.30\end{array}$ & $\begin{array}{l}1.00 \\
0.6 \\
0.27\end{array}$ & $\begin{array}{l}1.00 \\
0.3 \\
0.5 \\
0.23\end{array}$ & $\begin{array}{r}100 \\
46 \\
39 \\
22\end{array}$ \\
\hline 混 & 合 糖 & 転 化 糖 & $\mathrm{C}_{6} \mathrm{H}_{12}$ & ${ }_{6}+\mathrm{C}_{6} \mathrm{H}_{12} \mathrm{O}_{6}$ & 1.23 & 1.00 & $0.8 \sim 0.9$ & & 95 \\
\hline \multicolumn{2}{|c|}{ 糖アルコール } & \multirow{2}{*}{$\begin{array}{l}\text { ソルピトール } \\
\text { マンニトール }\end{array}$} & \multicolumn{2}{|c|}{$\mathrm{C}_{6} \mathrm{H}_{14} \mathrm{O}_{6}$} & & 0.51 & 0.48 & & 51 \\
\hline \multirow{2}{*}{\multicolumn{2}{|c|}{ " }} & & \multirow{2}{*}{\multicolumn{2}{|c|}{$\begin{array}{l}\mathrm{C}_{6} \mathrm{H}_{14} \mathrm{O}_{6} \\
\mathrm{C}_{6} \mathrm{H}_{14} \mathrm{O}_{6}\end{array}$}} & & & 0.45 & & 69 \\
\hline & & ダルシトール & & & & & 0.41 & & 41 \\
\hline
\end{tabular}

性などの食品衛生面に問題がないか， ii）工業的に量産 化の可能性など需給経済面にすぐれているか，iii）甘味 のし好性など特性有用面にすぐれているかなどからかな りの制約を受ける. 現在この三つの条件に一応パスして 甘味料として食品に利用されているものは, 次の 3 群の 甘味料である.

〔A群〕ヒドロキシル基を有する化合物を天然に含む 糖および糖アルコール：甘いものといえば砂糖というよ うに，通念的には糖類は甘いということになるが，表 2 に例示したように，甘味をもつ糖は単糖類と少糖類の範 囲内のもので，多糖類になるとデキストリンがわずかに 甘昧を呈する程度であって，でん粉になるとまったく甘 味を呈しない. 少糖類でも三糖類のラフィノースは甘味 度が低く, 二糖類と単糖類が甘い糖類ということになる が，同じ化学式をもっていてもかなり甘味度を異にして いる.これら糖類の化学構造と甘味度の関係については, 1947 年都築5) が単桾のアノメリック水酸基とその隣の 水酸基が，シス配位をとったとき甘味を呈するととを指 摘し，その後 Shallenberger ら6)の 1963〜65 年にかけ てのレポートでは, 糖の甘味の強さは, それらの分子内 水素結合の強さが強くなるにつれて弱くなることを指摘 し，これを立体配座と結びつけ，糖が甘味を呈する構造 的要素として, 隣合った水酸基がゴーシュあるいはスタ ガード配座をとることをあげた。

一般に二糖類および単糖類の単離製品もしくは混合製 品, およびこれらを含む天然産のはちみつ,メープルシ ラップなどを糖質甘味料と総称している。なお，単糖の 高圧還元, 電解還元によって工業的に合成（水素添加） され糖アルコール類も甘味を有する.ソルビトールは食 品添加物に指定されているが使用基準はない. マンニト 一ルは使用基準によって，あめ菓子類の粘着防止という 使用目的に規制されている.

〔B群〕糖以外の甘味成分を含先エキスまたはエキス
末天然甘味料 : グリチルリチンを含む甘草, フィロズル チンを含む甘茶，ステビオサイドを含むステビアなどの エキスまたはエキス末などが，糖以外の天然甘味料とし て使用されているが，前記 3 条件がじゅうぶんにチェッ クされたとはいえない点が少なくない.

〔C群〕食品添加物の指定を受けた化学的合成品の甘 味物質 : わが国では食品衛生法で化学的合成品の甘味物 質は，厚生大臣の食品添加物の指定をうけなければ，食 品に使用し販売に供することが禁止されている．現在食 品添加物に指定されている人工（合成）甘味料は，スル ホアミド基を有する化合物のサッカリンおよびサッカリ ンナトリウムと，グリチルリチン酸塩のグリチルリチン 酸二ナトリウムおよびグリチルリチン酸三ナトリウムで ある.これらには使用基準があって, 対象食品や使用量 の最大限度などが規制されており，またこれを使用した 食品にはその旨を標示することが義務ゔけられている.

\section{$2 \cdot 3$ 甘味物質の定量分析と甘味の計測}

甘味料の純度を測定する方法としては，それぞれの甘 味物質の物理的性質や化学構造 ·反応性に基うく測定方 法があるが，甘味物質の純度が必ずしも甘味の計測值 一甘甘味度（甘味の強さ, 甘味の濃度）——を意味しな いことが少なくない. したがって加工食品中の甘味物質 を定量分析しても, 甘味の大小・強弱を傾向的にとらえ る程度であって，甘味の数量化にはふじゅうぶんであ る. むしろ, これら甘味物質の検出・定量分析は, 前記 の人工（合成）甘味料の使用基準のチェックとか, 食品 の成分規格の検定とか, 品質性状变化の指標として甘味 物質成分の定量分析が行なわれる。

糖の定量分析は種類と特性に基づいて計測される. 食 品中に存在する多くの糖類は, 化学的に還元性を有する 還元糖と，還元を示さない非還元糖より成るが，非還元 糖は加水分解によって還元糖に変光ることができる．還 
元糖は還元基と呼ばれる遊離のアルデヒド基，あるいは ケトン基を有する還元性を示す糖類であり, 遊離の単糖 はすべて還元糖である. 少糖類ではマルトースのように 一端に還元基をもち還元性を有するものと，しょ糖のよ うに還元基が互いに結合して非還元性のものとがある. 多糖類は末端に還元基を有するが，全体に少ないために 強い還元性を示さない，栄養価の測定など通常の食品分 析においては, 構成糖を個々に定量することなく, 試料 を加水分解して非還元糖をも含めた糖類全体を一括して 還元糖として定量し，この全糖量を略して全糖と称して いる. 全糖の定量には存在する還元糖の還元力を利用し た方法としてベルトラン法7)，レイン・エイノン法8), ソモギー法9) 11) ならびにその改良または変法 ${ }^{12)}$ も数多 く知られているが, 分析の目的, 試料の種類に忍じて適 当な方法を用いる必要がある. デキストリンの定量はべ ルトラン法で還元糖を定量し，これの值に $0.9\left[\left(\mathrm{C}_{6} \mathrm{H}_{10}\right.\right.$ $\left.\left.\mathrm{O}_{5}\right)_{n}(162.1 \times n)+n \mathrm{H}_{2} \mathrm{O} \rightarrow n\left(\mathrm{C}_{6} \mathrm{H}_{12} \mathrm{O}_{6}\right)(180.1 \times n)\right]$ を 乗じてデキストリン量とする. しょ糖の定量はレイン・ エイノン法により転化糖量を定量し, その值に $0.95\left[\mathrm{C}_{12}\right.$ $\left.\mathrm{H}_{22} \mathrm{O}_{11}(342.2)+\mathrm{H}_{2} \mathrm{O} \rightarrow 2\left(\mathrm{C}_{6} \mathrm{H}_{12} \mathrm{O}_{6}\right)(180.1 \times 2)\right]$ を乗じ てしょ糖量とする. また，しょ糖純度の計測にはしょ糖 の旋光性を利用して 比旋光度を計測し 糖度換算する方 法13)がある. 非還元糖は加水分解によって還元糖に変わ るが，以前から存在している糖を直接還元糖または略し て直糖ともいう．直糖含量が多い場合はレイン・エイ， ン法が，微量の場合はオフナー法 ${ }^{14)}$ が用いられる.さら に混合糖系から構成糖を個々に分別定量する方法として は, クロマトグラフィーなどで単離してから各糖の定量 を行なえば，かなり的確に分別定量できるが，簡易分別 定量法としての「ぶどう糖・果糖の分別定量法」には, i ) システィンーカルバゾール法によるケトースの定量 法 $^{15) 16)}$, ii）ウィルシュテッターーシューデル法による アルドースの定量法 ${ }^{17) 18)}$, iii）酵素法（グルコースーオ キシダーゼ）によるぶどう糖の分別定量法 ${ }^{19)}$ ，iv）その 他アルドースの定量法として Klein-Acree 法"20), ケト ースの定量法として $\alpha$-ナフトール法21)，レゾルシンーチ オウレア法22) 23), ジフェニルアミン法24), レゾルシン塩 酸法淿)などがある.「ぶどう糖とマルトースの分別定量 法」としては，全還元糖をソモギー変法12)で求め，その 全還元糖からグルコースーオキシダーゼ法で定量したぶ どう糖量を差し引いた值を，マルトース量に換算する方 法もある.

食品中のソルビトールの定量分析法には, Ratsch ら 26) や Turner ら ${ }^{27)}$ が行なった抽出前処理液の旋光度を測定 し定量する方法, Minsker ${ }^{28)}$ が食酢中のソルビトールを トリーoークロルベンズアルデヒドーソルビトールにして重 量法で測定する方法, Haeseler ら 29)が行なった果じゅう 中のソルビトールを TLC で定量する方法もあるが，比 較的多用されている簡便法は過ヨウ素酸酸化による滴定 法で，Hundley ら ${ }^{30)}$ ，藤井ら ${ }^{31)}$ の報告がある. そのほ か $\mathrm{Graham}^{32)}$ によるアンスロン試薬を用いた比色法や， Jones ら ${ }^{33)}$ や岩田ら ${ }^{34)}$ の行なったガスクロマトグラフィ 一による方法などもある・いずれの方法も食品試料から の抽出, 単離, 反応定定量的に行なうための条件に問題 がある.

グリチルリチンの定量法には，黒野ら ${ }^{35)}$ のいそう土 薄層クロマトグラフ法, および羽田ら ${ }^{36)}$, 田中 ${ }^{37)}$ のペー パークロマトグラフ法, 野崎ら ${ }^{38)}$ のガスクロマトグラフ 法がある.

サッカリンの定量法については，ズルチン・サッカリ ン・サイクラミン酸塩が混在している場合の系統的試験 法として，厚生省の衛生検査指針の分析法に記載されて

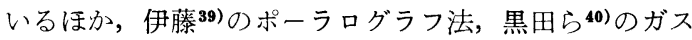
クロマトグラフィーによる食品中のサッカリンナトリウ ムの定量法, Conacher ら ${ }^{41)}$ のガスクロマトグラフ法に よる清涼飲料中のサッカリンの定量, Robert42) のガス クロマトグラフ法による体液, 尿などの中のサッカリン の定量などの報告がある.

\section{4 官能によって呈味力を測定する方法}

甘味物質の純度や食品中の甘味物質の定量分析值は, 必ずしも甘味の強さを示すとはかぎらないので，官能に よって呈味力を測定する方法が行なわれている．この測 定法は一般に官能検査と呼ばれている.官能検查におい て, 味の基本的特性は単独の水溶液および他の呈味成分 との相互作用において測定されるが，食品への利用とい う立場からいえば，その測定結果は単に甘味度という量 的なものばかりでなく，味質という質的評価もきわめて 重要である. 呈味力の強弱をみる量的な問題は比較的取 り扱いが容易であるため，表 1 および 2 にも例示したよ うに交献数も多いが，味質に関する研究はあまり進んで いないので報告が見あたらない，呈味力の強弱をみるの にしばしば刺激圏が測られるが，いき值は被験者や測定 方法 (温度, $\mathrm{pH}$, 呈味配列順序) などによって左右され やすいし，物質によって濃度と味の伸び率の関係が異な るという報告43) もあり, 呈味力は濃度の関数として連続 的にとらえる必要がある. したがって各甘味度を比較す る場合，基準物質何\%のときのものか明らかでないと厳 密な比較はできない.甘味物質の甘味度が測定者・交献に よって幅があるのはこの点に基因しているものと思う. 
官能によって呈味力を測定する方法は 種々あるが44) 47) 甘味の強さを測定する場合は，しょ糖を基準物質として 相対的な甘味度で表わすのが実際的で便利である.

筆者らはPauli の全系列法48)を応用した次のような方 法49)で甘味度の測定を行なっている．まず，測定しよう とする試料の溶液を二つつくる，その一つはすべてのパ ネルにとって基準しょ糖液（グラニュ糖 $10 \%$ 水溶液を 標準とする）よりも甘味の大きいもの，他の一つは小さ いものとする. こうして求めた両端の濃度の間を $5 \sim 6$ に均分した濃度間隔の試料水溶液を調製する。この供試 液をランダムに配列し，パネルは各供試液を一つ一つ基 準糖液と比較し，甘味が「ょり大」「等しい」より小」 であるかの三件法をもって記述する。一とおり済えだら 順序を逆にして，ふたたび基準糖液と比較し記述する. すなわち各供試液についての判別数 $(n)$ はパネル数の 2 倍となる.さらに三件法による判別が済んでから， ラ ンダム配列を 低濃度液から高濃度液の順に並べ変えさ せ，この並べ替えた配列に誤りのある場合は，そのパネ ルの判別は無効とし棄却する. 各パネルの記述結果を集 計して甘味度を算出する方法は次のとおりである.

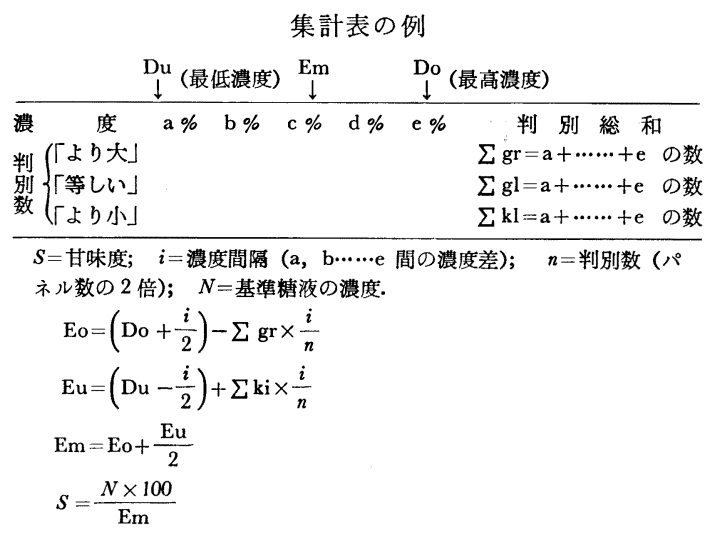

甘味の味質も官能検査で評価されるが，甘味度測定の 場合と同様にしょ糖の甘味感覚が基準におかれる. 筆者 らは 10\% グラニュ糖水溶液を基準とし，その甘味度に 相当する供試甘味料の水溶液を調製し，口当たり，のど ごし，甘味の好み，うまみ，あと味の切れなどのチェッ クポイントを設け，これを次のような採点基準で評価採 点する.

$\begin{array}{ccccccccc}-4 & -3 & -2 & -1 & 0 & +1 & +2 & +3 & +4 \\ 1 & 1 & 1 & 1 & 1 & 1 & 1 & 1 & 1 \\ \text { 非常 } & \text { かな } & \text { 劣る } & \text { やや } & \text { 基 } & \text { やや } & \text { よい } & \text { かな } & \text { 非常 } \\ \text { に劣 } & \text { り劣 } & & \text { 劣る } & \text { 準 } & \text { よい } & & \text { りよ } & \text { によ } \\ \text { る } & & & & & & & \text { る } & \text { 小 }\end{array}$

各パネルの採点合計值から, 各供試甘味料のし好性順 位を有意差検定（危険率 5\%) し，乙好性評価に用い る. 甘味料はコーヒー, 紅茶などへの単用も加工食品へ の配合も, 単に甘味料だけの呈昧を味わうことはごくま れで，2種以上の呈味成分とよく調和寸る「塩なれ効 果」「酸なれ効果」などと呼ばれている調味性も重要な 味質である.一般にしょ糖似た味質つものほどよい甘 味とされるが，これは単に食習慣によるものであるから 絶対的な味質とはいえないという説もあるが, 食品用の 甘味料としてはその食習慣を無視することはできないと 思う.さらに食品の製造工程で甘味料の甘味度および䏞 質が， pH や加熱によって変化するかどうかも重要な性 質である.しょ糖の転化や着色, サッカリンナトリウム の分解などによる甘味度および林質の变化は, 食品製造 の立場からはふつごうな性状と評価される。

\section{$2 \cdot 5$ おわりに}

甘味の数量化は，ヒトに甘味感覚をひきおこさせる物 質が与えたその感覚を, 客観的にとらえる官能検査法に よるが, 感覚をひき起こさせる濃度, 温度, $\mathrm{pH}$ などの 測定条件と, 試料の品質（甘味物質の純度など）が明記 されることが必要である。食品製造の立場からいえば， 甘味の強さを甘味度と表示するばかりでなく, 味質の評 価も併記されることが望ましい，これらの知見をささえ るもとの実験データは, 多数のパネルに各自基準物質液 と供試物質液とを与え, どちらがより強いか, より好ま しいか, ぞれだけ違うかを答えさせる識別法, ないしは 評点法の操作㖣述をくりかえさせて得られるものであ る. その意味ではパネルの主観に基ゔくものとはいえ, くりかえしという操作により偶発的な識別や評価が避け られ，集計で統計的処理安行なうので，客観的な判断に よるものとみてよいだろう.

\section{文献}

1) Hackh's Chemical Dictionary, p. 85 (1944).

2) H. G. Schutz, F. J. Pilsrim : Food Research, 22, 206 (1957).

3) R. W. Moncrief : "The Chemical Senses", 3 rd Ed., p. 535 (1967), (Leonard Hill, London).

4) G. Nieman : Zucker und Süsswaren-Wirtschaft., 11, 467 (1958).

5) 都築洋次郎: 科学, 24, 523 (1954).

6) R. S. Shallenberger : J. Food Sci., 28, $584(1963)$; Agr. Sci. Rev., 2, 11 (1964); New Sci., 23, 569 (1964); J. Food Sci., 30, 500 (1965).

7) G. Bertrand : Bull. Soc. Chem. (Paris), 35, 1285 (1906).

8) J. H. Lane, L. Eynon : J. Soc. Chem. Ind., 17, $32 \mathrm{~T}$ (1923); 19. $150 \mathrm{~T}$ (1925). 
9) P. A. Shaffer, M. Somogyi : J. Biol. Chem., 100, 695 (1933).

10) M. Somogyi : ibid., 160, 61 (1945).

11) M. Somogyi : ibid., 195, 19 (1952).

12）小林達吉, 田淵武士 : 農化, 28, 171 (1954).

13）精糖技術研究会：“製糖便覧”，p. 18 (1962)，（朝 倉書店).

14) Offical Method of Analysis of The Association of Official Agricultural Chemists, p. 509 (1950).

15) Z. Dishe, E. Borenfreund : Biol. Chem., 192, 583 (1951).

16)松尾義之, 南波 章 : 醱酵工学, 36, 342(1958).

17) R. Willstätter, G. Schudel : Ber., 51, 780 (1918).

18）貝沼寺二，田所克子，鈴木繁男：澱粉工誌，12, (2), 57 (1965).

19) D. Keilin, E. F. Hartree : Biochem. J., 42, 230 (1948).

20) London John Willey \& Sons, Physical \& Chemical Method of Sugar Analysis 3rd, p. 898 (1941).

21）武島達夫，緑川 沉 : 科研報告， 24，(5)，252 (1948).

22) J. H. Roe, J. H. Epstein : J. Biol. Chem., 178, 899 (1946).

23）貝沼圭二, 田所克子，鈴木繁男：澱粉工誌， 12, (4), 135 (1965).

24) A. G. Corcaran, I. H. Page : J. Biol. Chem., 127, 601 (1939).

25) R. G. Kulka : Biochem. J., 63, 542 (1956).

26) A. Ratsch, G. Freise : Deut. Lebensm. Rundschau., 60, 343 (1964).

27) A. Turner : Analyst, 89, 115 (1964).

28) F. Minsker : J. Assoc. Offic. Ager. Chemists, 45,
562 (1962).

29) G. Haeseler, K. Misselhorn : Z. Lebensmitt, Untersuch u., 129, 71 (1966).

30) H. K. Hundley, D. D. Hughes : J. Assoc. Offic. Agr. Chemists, 49, 1180 (1966).

31) 藤井清二, 細貝祐太郎, 岡田太郎, 伊藤 肇 : 食 衛誌, 9, 322 (1968).

32) H. D. Graham : J. Food Sci., 28, 440 (1963).

33) H. G. Jones, D. M. Smith, M. Sahasrabudhe : J. Assoc. Offic. Agr. Chemists, 49, 1183 (1966).

34）岩田有三，佐々木義幸，折口和範，小島 炳：食 品工誌, 20, (2), 60 (1973).

35）黑野吾市，佐々木冴美 : 薬誌，90，497 (1970).

36) 羽田栄彦, 稲垣瑞穂 : 同上, 78, 795 (1958).

37) 田中達雄：生化学，40,817 (1968).

38) 野崎正勝, 鶴見介堂, 藤村 一：薬誌，90,693 (1970).

39) 伊藤 沉 : 精糖技研誌, 22, 54 (1970).

40）黑田弘之，広瀬秀雄：食衛誌，12，322 (1971).

41) H. B. S. Conacher, R. C. O. Brien : J. Assoc. Offic. Agr. Chemists, 53, 1117 (1970).

42) R. J. Daum : J. Assoc. Offic. Anal. Chemists, 154, 1140 (1971).

43) S. Yamaguchi, et al.: Agr. Biol. Chem., 34, 181 (1970).

44) A. T. Cameron : Sci. Rept. No. 9, Sugar Foundation, Inc., N. Y. (1947).

45) H. G. Schutz, et al. : Food Res., 22, 206 (1957).

46) R. M. Pangborn : J. Food Sci., 28, 726 (1963).

47) H. Stone, et al. : ibid., 34, 215 (1969).

48) R. Pauli : Biochem. Z., 125, 97 (1921).

49）渡辺長男：澱粉糖技研報，14，44（1956)。

\section{3 酒の味について}

\section{$3 \cdot 1$ はじめに}

酒精飲料である酒は米，麦からの清酒やビール，ぶど うからのワイン, 蒸留酒のウイスキー, ブランデーなど 原料, 製造法, 微生物の違いなど多種多様で, 酒精含量 も5〜 40\% ときわめて広範囲にわたり，成分も酒の種類 によって大きな違いがある.したがって，個々の酒の風 味は基本的なアルコールの香味を除けば各酒類に固有で 多岐にわたっている.これら全酒類の味を一括して述べ

\footnotetext{
* 理化学研究所 : 埼玉県和光市広沢 2-1
}

ることは紙面のつごう上，また，筆者の及ぶところでも ないので，ここでは清酒に限りその概要を紹介するにと どめたい。

清酒の風味の本質を知るためには微量成分に至るまで 化学分析を進め, 官能的評価を加え香味構成を笨める必 要のあることはもちろんで，このような観点から香昧成 分の検索は古くから行なわれ，多くの成果が得られてい る. 本稿では現在までに知られた成分や呈味と清酒の風 味の概要について紹介することとする. 